\title{
Honeybee-collected pollen from five Portuguese Natural Parks: Palynological origin, phenolic content, antioxidant properties and antimicrobial activity
}

\author{
Margarida Morais ${ }^{a}$, Leandro Moreira ${ }^{a}$, Xesús Feás ${ }^{\mathrm{b}}$, Leticia M. Estevinho ${ }^{\mathrm{a}, *}$ \\ ${ }^{a}$ CIMO-Mountain Research Center, Agricultural College of Bragança, Polytechnic Institute of Bragança, Campus Santa Apolónia, E 5301-855 Bragança, Portugal \\ ${ }^{\mathrm{b}}$ Department of Analytical Chemistry, Nutrition and Bromatology, University of Santiago de Compostela, E-27002 Lugo, Galicia, Spain
}

\section{A R T I C L E I N F O}

\section{Article history:}

Received 15 November 2010

Accepted 27 January 2011

Available online 1 February 2011

\section{Keywords:}

Bee pollen

Palynological analysis

Antioxidant capacity

$\beta$-Carotene bleaching assay

DPPH

Antimicrobial activity

\begin{abstract}
A B S T R A C T
The aim of this study was to determine the palynological origin, phenolic content, antioxidant and antimicrobial properties of pollen from five Portuguese Natural-Parks [Parque Nacional Peneda Gerês (PNPG); Parque Natural do Montesinho (PNM); Parque Natural do Alvão(PNA); Parque Natural da Serra da Estrela (PNSE) and Parque Natural do Douro Internacional (PNDI)]. Eight families were found in the mixture of bee pollen: Rosaceae, Cistaceae, Boraginaceae, Asteraceae, Fagaceae, Ericaeae, Myrtaceae and Fabaceae. The phenolic compounds content, determined by the Folin-Ciocalteu method, varied between 10.5 and $16.8 \mathrm{mg}$ of gallic acid equivalents/g of extract (mg GAE/g) found in bee pollen from PNM and PNDI, respectively. The free radical scavenging measured showed the highest effective extract - PNM with $\mathrm{EC}_{50}$ 2.16, followed by PND with $2.24 \mathrm{mg} / \mathrm{mL}$. In the $\beta$-carotene bleaching assay the same behaviour as in the DPPH method was verified. We also verified that the presence of pollen differentially affected the growth of bacteria Gram-positive, Gram-negative and yeasts under study, depending this on the microorganism and the pollen used. This is an important study since, as far we know, it is the first time that Portuguese bee pollen from Natural Parks was studied, and their characterization can increase their economic value.
\end{abstract}

(c) 2011 Elsevier Ltd. All rights reserved.

\section{Introduction}

Apiculture is an economic activity which is firmly established in Portuguese agriculture, and which is directed almost completely to the production of high quality honey. Nowadays, consumers are more and more interested in natural products and Portuguese honey is strongly affected by the commercialization of honey from Asia and South America, which is sold bellow the production cost. Thus, it is very important to set out alternatives, such as honeybee-collected pollen. The production of bee pollen might help to increase economic profits and thus help beekeepers to rectify their financial difficulties. In fact, pollen production on a national level is scarce, and does not satisfy the current consumer demand. As result, most of the pollen consumed in Portugal comes from Spain (Ministério da Agricultura do Desenvolvimento Rural e das Pescas, 2007).

Honeybees collect bee pollen in order to use it as food for all the developmental stages in the hive. Pollen is a fine, powder-like material produced by flowering plants and gathered by bees. Pollens grains are the male reproductive cells of flowers (Basim et al., 2006). Flower pollens, whose composition can vary due to their botanical and geographic origin (Almaraz-Abarca et al.,

\footnotetext{
* Corresponding author. Tel.: +351 273 303342; fax: +351273 325405 .

E-mail address: leticia@ipb.pt (L.M. Estevinho).
}

2004), contain carbohydrates, amino acids, proteins, lipids, vitamins, minerals, phenolic compounds, flavonoids, concentrations of phytosterols and are also rich in phytochemicals (Balch and Balch, 1990; Broadhurts, 1999; Carpes, 2008).

Phytochemicals, such as phenolic compounds are considered beneficial for human health since they decrease the risk of degenerative diseases by reducing oxidative stress and inhibiting macromolecular oxidation (Silva et al., 2004; Pulido et al., 2000). They have been shown to possess free radical-scavenging and metalchelating activity in addition to their reported anticarcinogenic properties (Middleton, 1998). Bee pollen has also been successfully used for the treatment of some cases of benign prostatitis and for oral desensitization of children who have allergies (Campos et al., 1997; Mizrahi and Lensky, 1997).

There are some reports about the antimicrobial (Basim et al., 2006; Carpes et al., 2007) and antioxidant (Campos et al., 2003; Carpes et al., 2007; LeBlanc et al., 2009) activities of pollen separated into families. However, it should be noted that this is the first study about mixed pollen, and how it is commercialized by beekeepers. We decided to use mixed pollen because it would be economically impossible for the beekeepers to separate the pollens into families before selling it.

The aim of the present work is to determine the botanical origin and to evaluate the phenolic content, antioxidant and antimicrobial properties of pollen from five Portuguese National Parks. This 
is a very important study since as far we know it is the first time that this hive product from Natural Parks is investigated and this study might help to increase its economic benefit.

\section{Materials and methods}

\subsection{Chemicals}

2,2-Diphenyl-1-picryl-hydrazyl (DPPH) was obtained from Alfa Aesar (Ward Hill, MA, USA). 3,4,5-Trihydroxybenzoic acid (gallic acid; GA), 2,3,5-triphenyl tetrazolium chloride (TTC), tert-butylhydroquinone (TBHQ), butylated hydroxyanisole (BHA), linoleic acid (LA), polyoxyethylene (20) sorbitan monooleate (Tween 80), $\beta$-carotene, dimethyl sulfoxide (DMSO) and ethanol were obtained from Sigma Chemical Co. (St. Louis, MO, USA). The Folin-Ciocalteu reagent, chloroform $\left(\mathrm{CHCl}_{3}\right)$, sodium carbonate $\left(\mathrm{Na}_{2} \mathrm{CO}_{3}\right.$ ), gentaminice and fluconazol were obtained from Merck (Darmstadt, Germany). Methanol (MeOH) was obtained from Pronolab (Lisboa, Portugal). High purity water $(18 \mathrm{M} \Omega \mathrm{cm})$, which was used in all experiments, was obtained from a Milli-Q purification system (Millipore, Bedford, MA, USA).

\subsection{Apparatus}

Spectrophotometric measurements were made using a Unicam Helios Alpha UV-visible spectrometer (Thermo Spectronic, Cambridge, UK). Evaporation of organic solvents were performed with a rotavapor system, consisting of a rotary vacuum evaporator (Heidolph VV. 2000, Leuven, Belgium) with a water bath and a B169 vacuum pump (Büchi, Flawil, Switzerland). The examination of the pollen slides was carried out with a Leitz Diaplan microscope (Leitz Messtechnik GmbH, Wetzlar, Germany).

\subsection{Bee pollen samples}

The bee pollen was collected by the beekeepers between January and July of 2009, from separate apiaries located in five Portuguese Natural Parks: Parque Nacional Peneda Gerês (PNPG), Parque Natural do Montesinho (PNM), Parque Natural do Alvão (PNA), Parque Natural da Serra da Estrela (PNSE) and Parque Natural do Douro Internacional (PNDI) (Fig. 1). The selected beehives were equipped with bottom-fitted pollen traps. After the beekeepers dried the bee pollen, the samples were delivered to the Microbiology Lab, where they were stored in a dark place at room temperature $\left( \pm 20^{\circ} \mathrm{C}\right)$.

\subsection{Palinological identification}

The palinological identification of the bee pollen was performed by the method described by Almeida-Muradian et al. (2005). Briefly, a sample of $2 \mathrm{~g}$, corresponding to more or less 300 pollen pellets, was considered to be representative for botanical origin. The pellets were grouped into subsamples according to colour (light yellow, amber, dark yellow, dark brown, grey, light olive, red yellow and orange) and each subsample (botanical family) was then weighed to calculate its percentage in the main sample. One pollen microscope slide of each subsample was prepared by washing the pollen in 50\% ethanol and using glycerin jelly and paraffin for permanent preparations following Barth (1989). Pollen grain identification was per-

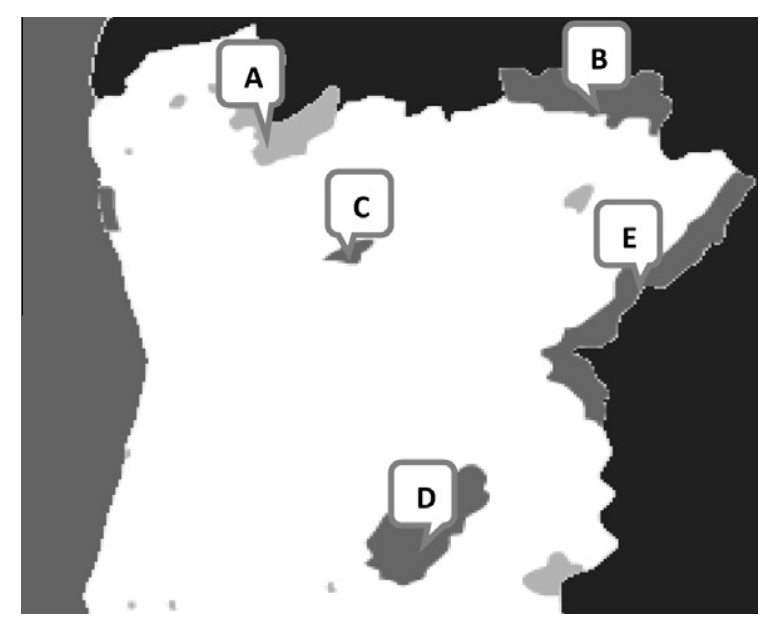

Fig. 1. Map of Portugal marked with Natural/National Parks: (A) Parque Nacional da Peneda Gerês (PNPG); (B) Parque Natural de Montesinho (PNM); (C) Parque Natural do Alvão (PNA); (D) Parque Natural da Serra da Estrela (PNSE); (E) Parque Natural do Douro Internacional (PNDI). formed by optical microscope with total magnification $(400 \times$ and $1000 \times)$. A reference collection of the Escola Superior Agrária de Bragança - Instituto Politécnico de Bragança, and different pollen morphology guides were used for the recognition of the pollen types.

\subsection{Extracts preparation}

For the preparation of sample extracts, the method reported by Moreira et al. (2008) was used, with minor modifications. Briefly, bee pollen and $\mathrm{MeOH}$ were mixed (1:2) (w/v) and left to macerate for $72 \mathrm{~h}$ at room temperature. After this time, the solution was filtered by Whatman filter paper No. 4 and the solid residue was re-extracted. Then, the $\mathrm{MeOH}$ extracts were combined and evaporated in a vacuum evaporator. Finally, the dried extract of pollen was stored in the dark at room temperature, for further analysis.

\subsection{Estimation of total phenolic contents}

The total phenolic content in the pollen extract was estimated according to the Folin-Ciocalteau method described by Moreira et al. (2008). Briefly, the reaction of $500 \mu \mathrm{L}$ pollen extract in $\mathrm{MeOH}$, mixed with $500 \mu \mathrm{L}$ of the Folin-Ciocalteau reagent and $500 \mu \mathrm{L}$ of $\mathrm{Na}_{2} \mathrm{CO}_{3}(10 \% \mathrm{w} / \mathrm{v})$ was kept in the dark at room temperature for $1 \mathrm{~h}$, after which the absorbance was read at $700 \mathrm{~nm}$. GA standard solutions $(0.01-0.08 \mathrm{mM})$ were used for constructing the calibration curve $\left(y=2.3725 x+0.0021 ; R^{2}=0.9\right)$. Total phenols content were expressed as $\mathrm{mg}$ of GA equivalents/g of extract (GAEs).

\subsection{Antioxidant activity}

The antioxidant properties of the pollen extracts were evaluated according to the DPPH method and $\beta$-carotene bleaching (BCB) assay.

\subsubsection{Scavenging of DPPH radicals}

The scavenging of DPPH radical was assayed following the method described by Ferreira et al. (2009). Various concentrations of $\mathrm{MeOH}$ extracts of pollens (300 $\mu \mathrm{L})$ were mixed with $2.7 \mathrm{~mL}$ of $\mathrm{MeOH}$ solution containing DPPH radicals $\left(6 \times 10^{-5} \mathrm{~mol} /\right.$ L). The mixture was shaken vigorously and left to stand for 60 min in the dark (until stable absorption values were obtained). The reduction of the DPPH radical was measured by continuously monitoring the decrease of absorption at $517 \mathrm{~nm}$. The radical-scavenging activity (RSA) was calculated as a percentage of DPPH discolouration using the equation: \%RSA $=\left[\left(A_{\mathrm{DPPH}}-A_{\mathrm{S}}\right) / A_{\mathrm{DPPH}}\right] \times 100$, where AS is the absorbance of the solution when the sample extract has been added at a particular level and $A_{\mathrm{DPPH}}$ is the absorbance of the DPPH solution. The extract concentration providing $50 \%$ of radical scavenging activity $\left(\mathrm{EC}_{50}\right)$ was calculated by interpolation from the graph of RSA percentage against extract concentration. The standards used were BHA and $\alpha$-tocopherol.

\subsection{2. $\beta$-Carotene bleaching $(B C B)$ assay}

The antioxidant activity of the methanolic extracts was evaluated by the $\beta$-carotene linoleate model system, as described by Ferreira et al. (2009). A solution was prepared by dissolving $2 \mathrm{mg}$ of $\beta$-carotene in $10 \mathrm{~mL}$ of $\mathrm{CHCl}_{3}$. Afterwards $2 \mathrm{~mL}$ of the aforesaid solution was pipetted into a $100 \mathrm{~mL}$ round-bottom flask. Then the $\mathrm{CHCl}_{3}$ was removed at $40{ }^{\circ} \mathrm{C}$ under vacuum. $40 \mathrm{mg}$ of linoleic acid, $400 \mathrm{mg}$ of Tween 80 emulsifier and $100 \mathrm{~mL}$ of distilled water were added to the flask. The mixture was shaken and $4.8 \mathrm{~mL}$ of this emulsion were transferred into different test tubes containing $200 \mu \mathrm{L}$ of different concentrations of the pollen extracts. The tubes were shaken and incubated at $50{ }^{\circ} \mathrm{C}$ in a water bath. As soon as the emulsion was added to each tube, the zero time absorbance was measured at $470 \mathrm{~nm}$ using a spectrophotometer. Absorbance readings were then recorded at 20-min intervals until the control sample had changed colour. A blank, devoid of $\beta$-carotene, was prepared for background subtraction (Mi-Yae et al., 2003). Lipid peroxidation (LPO) inhibition was calculated using the following equation: LPO inhibition $=(\beta$-carotene content after $2 \mathrm{~h}$ of assay/initial $\beta$-carotene content $) \times 100$. The extract concentration providing $50 \%$ antioxidant activity $\left(\mathrm{EC}_{50}\right)$ was calculated by interpolation from the graph of antioxidant activity percentage against extract concentration. TBHQ was used as standard.

\subsection{Antimicrobial activity}

The microorganisms used as test organisms are presented in Table 1. The microorganisms were isolated from aliments and identified in the Microbiology Laboratory of the Escola Superior Agrária de Bragança. The isolates were stored in Muller-Hinton medium plus $20 \%$ glycerol at $-70^{\circ} \mathrm{C}$. Before experimental use, cultures from solid medium were subcultivated in liquid media, incubated and used as the source of inoculums for each experiment. The inoculum for the assays were prepared by diluting cell mass in $0.85 \% \mathrm{NaCl}$ solution, adjusted to 0.5 MacFarland scale, confirmed by spectrophotometrical reading at $580 \mathrm{~nm}$ for bacteria and $640 \mathrm{~nm}$ for yeasts. Cell suspensions were finally diluted to $10^{4} \mathrm{CFU} / \mathrm{mL}$ in order to use them in the activity assays. 
Table 1

The microorganism tested.

\begin{tabular}{ll}
\hline Bacteria & Aliment \\
\hline Salmonella typhi ESA 101 & Chicken's meat \\
Staphylococcus aureus ESA 72 & Custard \\
Bacillus cereus ESA 55 & Cooked rice \\
Escherichia coli ESA 15 & Cheese \\
Zygosacharomyces mellis ESA 35 & Honey \\
Zygosacharomyces bailii ESA 1307 & Honey \\
Zygosacharomyces rouxii ESA 23 & Honey \\
Candida magnólia ESA 11 & Honey \\
\hline
\end{tabular}

Antimicrobial tests were carried out according to Duarte et al. (2007), using Nutrient Broth (NB) or Yeasts Peptone Dextrose (YPD) on microplate (96 wells). Pollen extracts were diluted in DMSO and transferred into the first well, and serial dilutions were performed. The inoculum was added to all wells and the plates were incubated at $37^{\circ} \mathrm{C}$ for $24 \mathrm{~h}$ (bacteria) and $25^{\circ} \mathrm{C}$ for $48 \mathrm{~h}$ (yeasts)

Fluconazol and gentamicine were used as controls. In each experiment a positive control (inoculated medium) and a negative control (medium), extracts' blanks (mediums with compounds) and DMSO control (DMSO with inoculated medium) was introduced. Antimicrobial activity was detected by adding $20 \mu \mathrm{L}$ of $0.5 \%$ TTC solution. The minimal inhibitory concentration (MIC) was defined as the lowest concentration of pollen extract that inhibited visible growth, as indicated by the TCC staining (dead cells are not stained by TTC).

\subsection{Statistical analysis}

All the determinations were carried out in triplicate. Measurements were averaged and the results are given as mean \pm standard deviation (SD). In each parameter, the differences between bee pollen samples were analysed using one-way analysis of variance (ANOVA) followed by Tukey's HSD test with $\alpha=0.05$, using SPSS (Statistical Package for Social Sciences).

\section{Results and discussion}

\subsection{Palynological identification}

On the basis of palynological analysis, all the samples were found to be heterofloral, due to their different colours and consequently different pollen types. It was proven that pollens with same colour belong to the same family. Eight families of pollen pellets were found in the mixture of bee pollen: Rosaceae (apple and sherry trees), Cistaceae (rock rose), Boraginaceae (honeyworth), Asteraceae (dandelion), Fagaceae (chestnut and oak), Ericaceae (heather), Myrtaceae (eucalyptus) and Fabaceae (wattle and clover) (Fig. 2).
The Cistaceae family was dominant $(>45 \%)$ in the PNSE and PNDI, while the Boraginaceae and Myrtaceae families were dominant in the samples from the PNA and PNPG, respectively. In the PNM sample no dominant pollen was found. With the exception of the PNDI, PNA and PNSE, all the samples included the Cistaceae family as an accessory pollen (15-45\%). Ericaceae, Myrtaceae and Rosaceae appear with high incidence in few samples (Ericaceae 26\% PNM; Rosaceae - 15\% PNA; Myrtaceae - 55\% PNPG).

None of the botanical families is represented in all the samples studied, since they have different origins. According to Luz et al. (2010) the pollen types observed in the pollen pellets can vary according to the region where they are offered, a factor which depends on the available surrounding bee pasture in the apiary vegetation, as well as on the climate conditions for flowering. These results are in line with those reported by Pires et al. (2005) and with the local vegetation which is more characteristic of the North and Centre regions of Portugal Leguminoseae, Fagaceae, Boraginaceae, Labiateae, Ericaceae and Cistaceae).

\subsection{Total phenolics content}

The obtained results showed that the phenolic compounds content, determined by Folin-Ciocalteu method, varied between the pollen extract, where the minimum and maximum was 10.5 and $16.8 \mathrm{mg} \mathrm{GAE} / \mathrm{g}$, for PNM and PNDI, respectively (Table 2). There were significant differences, using the Tukey test $(p<0.05)$, between total phenolic compound values obtained for the five pollen extracts.

Our results agreed with the ones obtained by Kroyer and Hegedus (2001) in pollen collected in Vienna de Austria; they were slightly superior to the results of Campos et al. (2003) in New Zealand and Portuguese pollens and a little below the data from Carpes et al. (2007) when analysing Brazilian pollens. According to Carpes et al. (2007), the pollen collected by bees generally shows characteristic amounts of total polyphenols due to its botanical and geographical origin. This situation can explain the observed differences between the samples, since each park has a singular and particular localization. For instance, Ericaceae was just found in PNM.

\subsection{Antioxidant activity}

Nowadays, antioxidants with natural origin are considered to be multifunctional, and interesting alternatives to synthetic antioxidants, and which can be used to prevent diseases and the oxidation

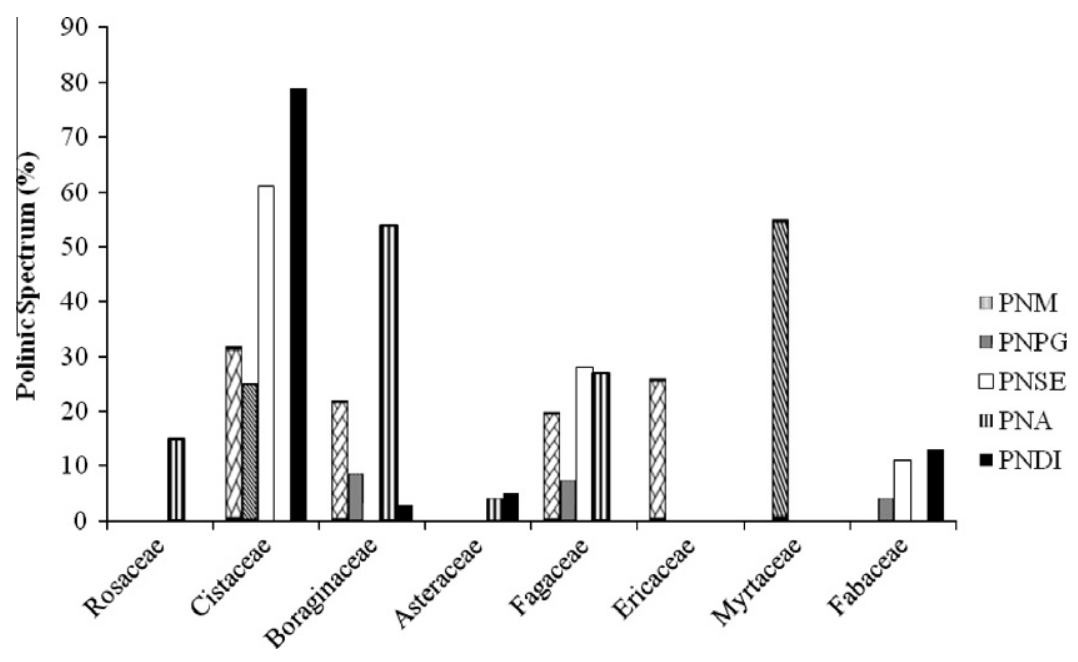

Fig. 2. Palynological spectrum of bee pollen samples. 
Table 2

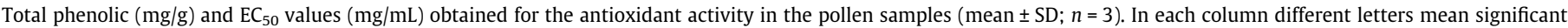
differences $(p<0.05)$.

\begin{tabular}{|c|c|c|c|}
\hline Pollen samples & Total phenols & $\mathrm{DPPH} \mathrm{EC}_{50}$ & $\beta$-Carotene bleaching \\
\hline Parque Nacional da Peneda do Gerês & $11.2 \pm 0.02 \mathrm{e}$ & $5.87 \pm 0.02 \mathrm{~d}$ & $6.52 \pm 0.02 \mathrm{e}$ \\
\hline Parque Natural de Montesinho & $10.5 \pm 0.01 \mathrm{c}$ & $2.16 \pm 0.02 b$ & $3.11 \pm 0.02 c$ \\
\hline Parque Natural do Alvão & $12.5 \pm 0.02 \mathrm{~d}$ & $3.23 \pm 0.02 c$ & $4.10 \pm 0.02 \mathrm{~d}$ \\
\hline Parque Natural da Serra da Estrela & $13.4 \pm 0.01 \mathrm{a}$ & $2.83 \pm 0.04 \mathrm{a}$ & $3.82 \pm 0.02 \mathrm{a}$ \\
\hline Parque Natural do Douro Internacional & $16.8 \pm 0.01 \mathrm{~b}$ & $2.24 \pm 0.06 \mathrm{~b}$ & $3.34 \pm 0.02 b$ \\
\hline
\end{tabular}

of complex food systems (Wang et al., 2008). Natural antioxidant activity depends on various parameters, such as the reaction mechanism, the experimental conditions and the heterogeneity of the matrix. The antioxidant properties of the pollen extracts cannot be evaluated by just one method due to the complex nature of their constituents. The use of at least two methods is recommended to assess and compare the antioxidant capacity of a sample (Sakanaka and Ishihara, 2008). In our research we used the DPPH method and the BCB assay.

\subsubsection{DPPH radical-scavenging activity}

The DPPH radical is one of the few stable organic nitrogen free radicals; it has been widely used to determine the free radical scavenging ability of the various samples. The free radical-scavenging activity of the extracts is attributed to their hydrogen-donating ability (Silva et al., 2006).

In DPHH assay, results are expressed as the ratio percentage of the absorbance decrease of DPPH radical solution in the presence of extract. Results were reported as the $\mathrm{EC}_{50}$, that is, the amount of antioxidant necessary to decrease by $50 \%$ the initial DPPH concentration (Antolovich et al., 2002).

The results of the DPPH radical scavenging activity of the different pollen samples are summarized in Table 2 . The extract concentration providing $50 \%$ inhibition $\left(\mathrm{EC}_{50}\right)$ was calculated from the graph of scavenging effect percentage against extract concentration (Chang et al., 2002; Moreira et al., 2008; Estevinho et al., 2008). The highest effective pollen extract was PNM and the lowest was PNPG, with $\mathrm{EC}_{50} 2.16$ and $5.87 \mathrm{mg} / \mathrm{mL}$, respectively.

The reduction of DPPH radical concentration together with the increase of pollen extract concentration was observed for all samples, and it was verified that the DPPH scavenging has a linear relation with the concentration. Bee pollen from different parks differed significantly $(p<0.05)$ in their DPPH radical scavenging percentage, with the exception of PNM and PNDI.

The experimental results of antioxidant activity of Portuguese pollen were superior to those found by Meda et al. (2005), who analysed 27 samples from Burkina Faso. These authors found a mean $\mathrm{EC}_{50}$ value of $10.60 \pm 7.30(\mathrm{mg} / \mathrm{mL})$. These values are similar to the results obtained by Leblanc et al. (2009). In this study the authors determined antioxidant activity rates that ranged between $19 \%$ and $90 \%$ for different types of pollen from Sonoran Desert.

Our results were also identical to the data by Campos et al. (2003). These authors found $\mathrm{EC}_{50}$ values that ranged from 40 to $500 \mu \mathrm{g} / \mathrm{mL}$ in pollen samples collected in Portugal and New Zealand. These authors claimed that the antioxidant activity of this natural product is largely a result of the phenolic compounds and flavonoids (quercitrin, 8-methoxyherbacetin, 7-methoxyherbacetin, 7-methoxyherbacetin-3-O-sophoroside, quercetin-3-O-sophoroside, luteolin, tricetin and myricetin), that have free radicalscavenging properties. Other constituents, like vitamins and proteins are also involved in this activity. In addition, AlmarazAbarca et al. (2004) verified that the antioxidant activity, in vitro and in vivo, is related to the amount of flavonols present. Our results revealed that there is no strong relation between the phenolic compounds and the antioxidant activity. Mărghitaş et al. (2009) used methanol as solvent and did not find any correlation between the phenolic content and the antioxidant activity. In addition, Silva et al. (2006) verified that antioxidant activities were different for each solvent tested (ethyl acetate > ethanol > hexane) and were not clearly associated to their total phenolic content.

\subsection{2. $\beta$-Carotene bleaching $(B C B)$ assay}

The $\beta$-carotene's bleaching mechanism is a free radical-mediated phenomenon, resulting from the hydroperoxides formed from linoleic acid. In the model system used, $\beta$-carotene undergoes rapid discolouration in the absence of an antioxidant. In the system tested, linoleic acid free radical, formed upon the abstraction of a hydrogen atom from one of its diallylic methylene groups, attacks the highly unsaturated $\beta$-carotene. As the molecules lose their double bonds by oxidation, the compound loses its characteristic orange colour, a fact that can be monitored spectrophotometrically (Sowndhararajan et al., 2010). The presence of antioxidants can hinder the extend of $\beta$-carotene-bleaching by neutralizing the linoleate-free radical and other free radicals formed in the system (Pereira et al., 2007).

The results obtained ( $\mathrm{EC}_{50}$ values) with the pollen extracts, are presented in Table 2. Our data indicated a concentration-dependent antioxidant capacity, following the order: $\mathrm{PNM}>\mathrm{PNDI}>$ PNSE $>$ PNA $>$ PNPG. However the protection of the $\beta$-carotene bleaching by the samples was lower than that provided by the TBHQ standard $(82.2 \%$ at $2 \mathrm{mg} / \mathrm{mL}$ ). Significant differences were observed between reducing power obtained for five analysed bee pollen.

Comparing the results of this study with values obtained in studies concerning other hive products such as entire honey, it is possible to observe that the data for $\mathrm{EC}_{50}$ are higher in honey: $37.03 \mathrm{mg} / \mathrm{mL}$ (dark honey), $39.25 \mathrm{mg} / \mathrm{mL}$ (ambar honey) and $75.51 \mathrm{mg} / \mathrm{mL}$ (light honey) (Ferreira et al., 2009). This fact suggests that the antioxidant activity of pollen is higher than honey.

In the present study, a great correlation between the obtained results in DPPH and $\beta$-carotene bleaching was found (data not shown). These results do not corroborate the observations of Carpes et al., 2007 (Brazilian pollen).

\subsection{Antimicrobial activity}

Figs. 3 and 4 show the antimicrobial activity screening of the five pollen extracts (from PNPG, PNM, PNA, PNSE, PNDI), on bacteria (Bacillus cereus, Staphylococcus aureus, Salmonella typhi and Escherichia coli) and yeasts (Zygosaccharomyces bailii, Zygosaccharomyces rouxii, Zygosaccharomyces mellis and Candida magnoliae). The MIC was used as a parameter of the significant inhibitory effects induced by bee pollen in the growth of the tested microorganisms. All the extracts evidenced antimicrobial activity, and showed different selectivity and MICs for each microorganism.

Gram-positive bacteria were inhibited by pollen extracts from PNM, at very low concentrations, presenting MICs of $0.17 \%(\mathrm{w} / \mathrm{v})$ for B. cereus, $0.21 \%(\mathrm{w} / \mathrm{v})$ for $S$. aureus. These bacteria were also inhibited by pollen extracts from other origins, but in the presence of higher extract concentrations. The pollen extract from PNPG was 


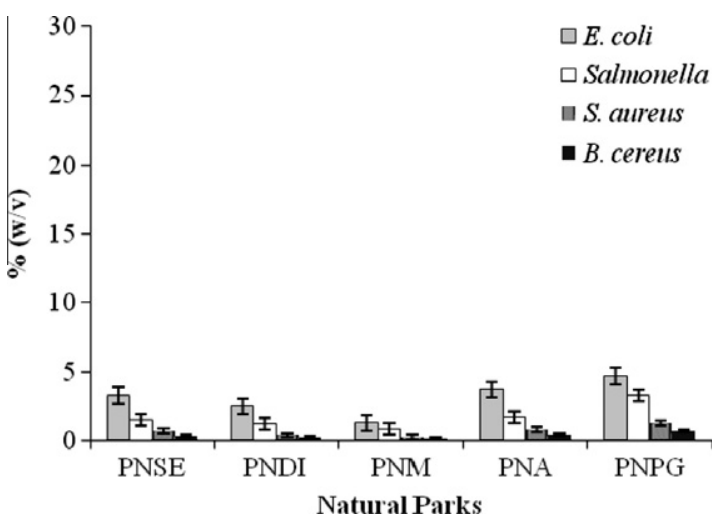

Fig. 3. Antibacterial activity of pollen extracts.

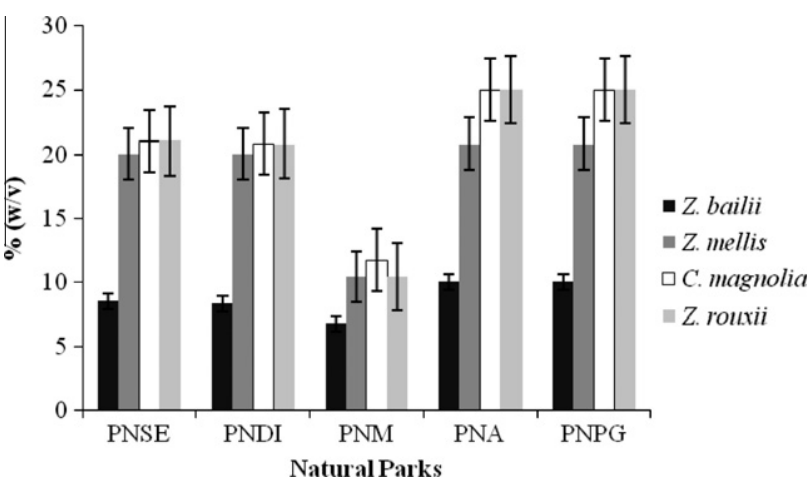

Fig. 4. Antifungal activity of pollen extracts.

the one that evidenced a lower antimicrobial activity, for all the microorganisms studied.

Gram-negative bacteria (S. typhi and E. coli) were also sensitive for some bee pollen extracts. PNM pollen extract was also the most effective in the Gram-negative growth inhibition. However, the MIC was superior to the one obtained for Gram-positive bacteria.

All the extracts demonstrated antifungal activity. Z. bailii, revealed to be the most sensitive yeast, because it was isolated from honey and it has probably not adapted to the stress conditions found in the methanolic extracts, namely, a high amount of proteins and phenolic compound content.

It was also found that the growth of yeasts under study were influenced by the type of pollen used; the most active pollen was PNM. As expected the standard gentamicine (antibacterial) and fluconazol (antifungal) presented lower MIC than the pollen extract (data not shown). Usually, the crude extracts show lower activity then the pure activity compounds.

Basim et al. (2006) verified that pollen from Turkey inhibited the growth of thirteen plant pathogenic bacteria, with Agrobacterium tumefaciens as the most sensitive and Pseudomonas syringae as the most resistant.

The studies carried out on the antimicrobial activity of Portuguese pollen are scarce, however, our team has ample experience in the determination of the antimicrobial activity of many natural products, such as honey (Estevinho et al., 2008; Gomes et al., 2010), olives (Pereira et al., 2006), mushrooms (Barros et al., 2007) and walnuts (Pereira et al., 2007). We verified that, as in the present work, the Gram-positive bacteria were more sensitive to bee pollen than the Gram-negative bacteria. The Gram-negative bacteria are more resistant because even though they have a flexible cell wall, they have a more complex chemical structure. One of the compounds in the wall, polysaccharide, determines the antige- nicity, toxicity and pathogenicity of the microorganisms. In addition, this bacterial group has a higher lipid amount than that observed in Gram-positive. The aforesaid characteristics might be key to the resistance of the extract tested. Some authors demonstrated that the antimicrobial activity is related to the total phenolic compounds (Pereira et al., 2007; Estevinho et al., 2008). However in this study no phenolic concentration dependence was observed. The extract of PNM, with lower total phenols was the most effective against microorganisms. This suggests that, other factors might be involved, such as the nature of the phenolic fraction.

\section{Conclusions}

The results obtained in this study demonstrated that bee pollen constitutes a good source of healthy compounds, namely, phenolics, and suggests that it could be useful in prevention of diseases in which free radicals are implicated. It is also notable that this product is a potential source of new antimicrobial agents; since an increasing number of bacteria are developing resistance to commercial antibiotics, extracts of bee pollen hold great promise for novel medicine in our time.

\section{Conflict of interest statement}

The authors declare that there are no conflicts of interest.

\section{Acknowledgements}

We would like to thank JoDee Anderson for his invaluable linguistic support.

This work was carried out in the framework of project PTDC/AGRALI/68240/2006.

\section{References}

Almaraz-Abarca, N., Campos, M.G., Avila-Reyes, J.A., 2004. Variability of antioxidant activity among honey-bee collected pollen of different botanical origin. Journal of Science and Technology of the Americas 29, 574-578.

Almeida-Muradian, L.B., Pamplona, L.C., Coimbra, S., Barth, O., 2005. Chemical composition and botanical evaluation of dried bee-pollen pellets. Journal of Food Composition and Analysis 18, 105-111.

Antolovich, M., Prenzler, P.D., Patsalides, E., McDonald, D., Robards, K., 2002. Methods for testing antioxidant activity. The Royal Society of Chemistry 127 183-198.

Balch, J.F., Balch, P.A., 1990. Prescription for Nutritional Healing. Avery Publishing Group Inc., New York. pp. 18-39.

Barros, L., Calhelha, R.C., Vaz, J.A., Ferreira, I., Baptista, P., Estevinho, L.M., 2007. Antimicrobial activity and bioactive compounds of Portuguese wild edible mushrooms. European Food Research and Technology 225, 151-156.

Barth, O.M., 1989. O pólen no mel Brasileiro. Rio de Janeiro, Editora Luxor

Basim, E., Basim, H., Ozcan, M., 2006. Antibacterial activities of Turkish pollen and propolis extracts against plant bacterial pathogens. Journal of Food Engineering 77, 992-996.

Broadhurts, C.L., 1999. Bee products: medicine from the hive. Nutritional Science News 4, 366-368.

Campos, M.G., Cunha, A., Markham, K.R., 1997. Bee pollen composition, properties and application. In: Mizrahi, A., Lensky, Y. (Eds.), Bee Products-Properties, Application and Apitherapy. Plenum Publishers, London, UK, pp. 93-100.

Campos, M.G., Webby, R.F., Markham, K.R., Mitchell, K.A., Da Cunha, A.P., 2003. Aged induced diminution of free radicals scavenging capacity in bee-pollens and the contribution of constituents flavonoids. Journal of Agricultural and Food Chemistry $51,742-745$

Carpes, T., 2008. Estudo das Caracteristicas Fisico-Quimicas e Biológicas do Polén Apícola de Apis mellifera da região Sul do Brasil. Tese apresentada ao Programa de Pós-Graduação em Tecnologia de Alimentos, Sector de Tecnologia da Universidade Federal do Paraná.

Carpes, T., Begnini, R., Matias de Alencar, S., Masson, M.L., 2007. Study of preparations of bee pollen extracts, antioxidant and antibacterial activity. Ciência e Agrotecnologia 31, 1818-1825.

Chang, L.W., Yen, W.J., Huang, S.C., Duh, P.D., 2002. Antioxidant activity of sesame coat. Food Chemistry 78, 347-354. 
Duarte, M.C., Leme, E.E., Delarmelina, C., Soares, A.A., Figueira, G.M., Startoratto, A., 2007. Activity of essential oils from Brazilian medicinal plants on Escherichia coli. Journal of Ethnopharmacology 111, 197-201.

Estevinho, L., Pereira, A.P., Moreira, L., Dias, L.G., Pereira, E., 2008. Antioxidant and antimicrobial effects of phenolic compounds extracts of Northeast Portugal honey. Food and Chemical Toxicology 46, 3774-3779.

Ferreira, I.C.F.R., Aires, E., Barreira, J.C.M., Estevinho, L.M., 2009. Antioxidant activity of Portuguese honey samples: different contributions of the entire honey and phenolic extract. Food Chemistry 114, 1438-1443.

Gomes, S., Dias, L., Moreira, L., Rodrigues, P., Estevinho, L., 2010. Physicochemical, microbiological and antimicrobial properties of commercial honeys from Portugal. Food and Chemical Toxicology 48, 544-548.

Kroyer, G., Hegedus, N., 2001. Evaluation of bioactive properties of pollen extracts as functional dietary food supplement. Innovative Food Science and Emerging Technologies 2, 171-174.

LeBlanc, B.W., Davis, O.K., Boue, S., DeLucca, A., Deeby, T., 2009. Antioxidant activity of Sonoran Desert bee pollen. Food Chemistry 115, 1299-1305.

Luz, C., Bacha Jr., G., Fonseca, R.L.E., Sousa, P., 2010. Comparative pollen preferences by africanized honeybees Apis mellifera L. of two colonies in Pará de Minas, Minas Gerais, Brazil. Annals of the Brazilian Academy of Sciences 82, 293-304.

Mărghitaş, L.A., Stanciu, O.G., Dezmirean, D.S., Bobis, O., Popescu, O., Bogdanov, S., Campos, M.G., 2009. In vitro antioxidant capacity of honeybee-collected pollen of selected floral origin harvested from Romania. Food Chemistry 115, 878-883.

Meda, A., Lamien, C.E., Romito, M., Millogo, J., Nacoulma, O.G., 2005. Determination of the total phenolic, flavonoid and proline contents in Burkina Fasan honey, as well as their radical scavenging activity. Food Chemistry 91, 571-577.

Middleton, Jr.E., 1998. Effect of plant flavonoids on immune and inflammatory cell function. Advances in Experimental Medicine and Biology 439, 175-182.

Ministério da Agricultura, do Desenvolvimento Rural e das Pescas, 2007. Programa Apícola Nacional Triénio de 2008-2010.

Mi-Yae, S., Tae-Hun, K., Nak-Ju, S., 2003. Antioxidant and free radicals scavenging activity of Phellinus baumii (Phellinus of Hymenochaetaceae) extracts. Food Chemistry 82, 593-597.

Mizrahi, A., Lensky, Y. (Eds.), 1997. Bee Products-Properties, Application and Apitherapy. Kluwer Academic Publishers, London, UK. p. 269.
Moreira, L., Dias, L.G., Pereira, J.A., Estevinho, L., 2008. Antioxidant properties, total phenols and pollen analysis of propolis samples from Portugal. Food and Chemical Toxicology 46, 3482-3485.

Pereira, J.A., Pereira, A.P., Ferreira, I.C.F.R., Valentão, P., Andrade, P.B., Seabra, R., Estevinho, L., Bento, A., 2006. Table olives from Portugal: phenolic compounds, antioxidant potential and antimicrobial activity. Journal of Agricultural and Food Chemistry 54, 8425-8431.

Pereira, J.A., Oliveira, I., Sousa, A., Valentão, P., Andrade, P., Ferreira, I., Ferreres, F., Bento, A., Seabra, R., Estevinho, L., 2007. Walnut (Juglans regia L.) leaves: phenolic compounds, antibacterial activity and antioxidant potential of different cultivars. Food and Chemical Toxicology 45, 2287-2295.

Pires, S.M.A., Rodrigues, T., Rocha, A., Pajuelo, A., Pereira, O., 2005. Pollen spectra of honeys from Trás-os-Montes e Alto Douro. Revista Portuguesa de Zootecnia 12 87-99.

Pulido, R., Bravo, L., Saura-Calixto, F., 2000. Antioxidant activity of dietary polyphenols as determined by a modified ferric reducing/antioxidant power assay. Journal of Agricultural and Food Chemistry 48, 3396-3402.

Sakanaka, S., Ishihara, Y., 2008. Comparison of antioxidant properties of persimmon vinegar and some other commercial vinegars in radical-scavenging assays and on lipid oxidation tuna homogenates. Food Chemistry 107, 739-744.

Silva, B.M., Andrade, P.B., Valentão, P., Ferreres, F., Seabra, R.M., Ferreira, M.A., 2004. Quince (Cydonia oblonga Miller) fruit (pulp, peel and seed) and jam: antioxidant activity. Journal of Agricultural and Food Chemistry 52, 4705-4712.

Silva, T.M.S., Câmara, C.A., Lins, A.C., Barbosa-Filho, J.M., Silva, E.M.S., Freitas, B.M., Santos, F.A.R., 2006. Chemical composition and free radical scavenging activity of pollen loads from stingless bee Melipona subnitida Ducke. Journal of Food Composition and Analysis 19, 507-511.

Sowndhararajan, K., Joseph, M.J., Arunachalam, K., Manian, S., 2010. Evaluation of Merremia tridentata (L.) Hallier f. for in vitro antioxidant activity. Food Science and Biotechnology 19,663-669.

Wang, H., Gao, X.D., Zhou, G.C., Cai, L., Yao, W.B., 2008. In vitro and in vivo antioxidant activity of aqueous extract frin Chobrospondias axillaris. Food Chemistry 106, 888-895. 